\title{
CHALLENGES OF NATION-BRANDING FOR STIMULATION OF LATVIAN EXPORTS
}

\author{
Angelina BEKASOVA ${ }^{1}$, Biruta SLOKA ${ }^{2}$, Tatjana MURAVSKA ${ }^{3}$ \\ ${ }^{1-3}$ University of Latvia, Latvia \\ Corresponding author e-mail: angelina.bekasova@gmail.com
}

\begin{abstract}
The presented research aims to contribute to the conceptualisation of the nation-brand of Latvia with the purpose of stimulation of national export performance. The subject of the research is three aspects presumably challenging the branding of Latvia with reference to national export development. The investigated challenges are the barriers and opportunities for green-branding of Latvia; the absence of the generally accepted indication of the geographical identity of the Baltic region; and the contradictable popular image of Latvia as a cheap country. The research poses two research questions inquiring into the issues of nation-branding of Latvia currently being faced in the context of exports and possible measures to overcome them. The applied research methods are theoretical analysis of scientific literature and empirical analysis of the representation of Latvia on the official website of the Investment and Development Agency of Latvia and its comparison with the official websites of respective institutions in Lithuania and Estonia. The research observes the interconnection between the defined challenges, offers the perspective for the possible transformation of the challenges into nation-branding opportunities, and estimates the green brand of the country as a gateway for feasible solution for the defined challenges and for the stimulation of national exports. In addition, the research identifies further challenges the nation-branding of Latvia is currently facing for further discussion.
\end{abstract}

Keywords: Challenges of nation-branding, export promotion, Latvia, nationbranding.

\section{INTRODUCTION}

The export sector of Latvia was pronounced to be a focal point of the development strategy of the Latvian economy (Ministry of Economics, Republic of Latvia, 2015). Nation-branding alongside with its associated terms like "made-in" campaigns is deemed to be a powerful tool for the stimulation of national export growth (Dinnie, 2008). This observation has been confirmed by academic researchers worldwide having made a solid research on the use of nation-branding tools to promote export advancement (Che-Ha et al., 2016; Mugobo, 2014).

More than a decade ago, a conclusion that Latvia has neither a clearly defined brand nor a branding strategy was reached (Endziņa \& Luneva, 2004; Vira et al., 2012). Disregarding a fair amount of research and advice on the issue that has been obtained thus far, the country still lacks a unified approach for positioning the country-brand and the enhancement of its presence on the global scene (Vira et al., 2012). This, however, does not mean that no efforts are being made to brand the 
country. For instance, Latvian Institute maintains a web portal Latvia.eu aimed at the promotion of "Latvia's positive international recognition" offering a readerfriendly and comprehensive representation of the country in four languages (Latvian Institute, 2016). In addition, with regard to the area of exports, Investment and Development Agency of Latvia (LIAA) facilitates foreign investments and competitiveness of Latvian entrepreneurs as well as publishes an all-embracing material useful for the potential international trade partners of the country as well as local entrepreneurs willing to participate in exports (LIAA, 2016). Certain advice on nation-branding strategies for Latvia has been obtained from the renowned experts in the area of nation-branding (Oxford Said Business School, 2003; Anholt, 2008). At the academic level, several researches have been conducted on nationbranding of Latvia with a focus on diverse aspects of the issue, e.g. place marketing in the context of regional development (Voznuka, 2010), destination marketing (Van der Steina, 2012), municipality marketing (Brencis, 2015) and place based research (Baltina, 2014). In turn, the topic of nation-branding in the context of stimulation of national export performance in Latvia remains an underexplored concern.

In order to forward the definition of a sound and consolidated nation-branding strategy, which would positively affect the export performance of Latvia, it is first reasonable to assume that the elucidation of the challenges of nation-branding of Latvia is of direct importance for the formulation of an efficient and sustainable nation-branding strategy. The aim of the present research is to investigate the challenges associated with nation-branding of Latvia. The research is based on three observed and hypothetically formulated inconsistencies related to the aspects influencing the brand of the country and its exports. The observed inconsistencies include 1) a considerable potential to brand Latvia as a green country based on its ecosystem and stunted development and maintenance of policies to support the green brand of Latvia, 2) a controversial geographical identity of the country varying across sources of opinion and 3) an established image of the country as cheap (in terms of the working force, services and production) and the actual and aspired state of the matter. The paper addresses two research questions: 1. Can the three defined inconsistencies be regarded as actual challenges of nation-branding of Latvia? 2. What are the possible measures to overcome them? Within the framework of the current research, the mentioned inconsistencies are investigated by evaluating the current state of the issue as well as the reasons and consequences of it. In addition, the research estimates possible solutions to the issues. The research serves the general purpose of facilitating the conceptualisation of the nation-branding strategy for Latvia.

\section{METHODS AND PROCEDURES}

To achieve the research aim, first, a theoretical analysis of scientific literature in the area of export management and nation-branding is performed. The theoretical analysis is extended by the empirical analysis of the information representing Latvia on the official website of Investment and Development Agency of Latvia (LIAA), the comparison of it with the content of the official websites of the respective 
institutions of Lithuania and Estonia (Invest Lithuania and Estonian Investment and Trade Agency) and by the estimation of the relevant statistical data.

The research is divided into three sections according to the formulated inconsistencies related to the conceptualisation of the nation-brand of Latvia. The first section examines the scientific publications, information and advisory sources on the possibility and its restrictions to form the brand of Latvia on the idea of the green brand, particularly in reference to exports (e.g. Dinnie, 2005; Iannuzzi, 2012; Environmental Performance Index, 2016; Cull, 2013; Vilcina et al., 2016, etc.). In addition, the research resorts to data analysis with the aim to evaluate the current environmental state of Latvia on the global and regional scale. Several aspects are covered including green production being oftentimes of increasing interest for importers and a vital facet of sustainable development. The second section is devoted to the discussion on the issue of the geographical identity of Latvia by analysing scientific and governmental sources (Endziña, Luneva, 2004; Vira et al., 2012; Dinnie, 2008; Szondi, 2007, etc.). The third section studies the challenge of nation-branding of Latvia expressed by the contradiction between the country image and the actual state of economic development expressed by the tokens "cheap/expensive". The section is based on scientific and informative research literature on the topic (Szondi, 2007; St. Amant, 2010; Cimdina, 2008; LIAA, 2016; Meel \& Saat, 2010, etc.). In each of the three research sections, possible directions for further consideration and analysis of the matter are indicated.

\section{CHALLENGE OF BRANDING LATVIA AS A GREEN COUNTRY}

The key factors associated with a positive influence on exports of a country via the nation-brand are high-quality brands of a country, an effective country image management, high levels of innovation and "the strategic development of target markets" (Dinnie, 2008). Environmental consciousness is a contemporary growing tendency on the global scale, which is being reflected by the increasing consumer demand for environmentally sound production (Iannuzzi, 2012; Dinnie, 2005). Therefore, eco-conscious lifestyle and products define a distinct market segment, whereas market pressures are regarded as among the strongest impetuses for the development of the green production industry (Iannuzzi, 2012). Accordingly, the natural environment of Latvia might offer a considerable potential for targeting the green market segment by accentuating the brand of a green country and thus to ensure an added value for the Latvian production in the green segment at the global level. To note, in the context of the current paper, the concept of a green brand of a country is framed by the ideas of environmentalism, improvement of the state of ecology at the national and global level, eco- and health-conscious lifestyle, the environmental pillar of sustainability and the like.

The approach of green-branding of Latvia was recommended by experts from Oxford Said Business School invited by the government of the Republic of Latvia in 2003 to advise on the brand identity of Latvia (Frasher et al., 2003). In addition, for the nation-brand of neighbouring Lithuania, Nicholas John Cull (Cull, 2013) advised to emphasise the country's "affinity with nature" and to base the nationbrand of Lithuania on the ideas of sustainability, thus making Lithuania "virtuous 
to other countries" to facilitate sustainable development also externally. In turn, according to the latest rankings of Environmental Performance Index, Lithuania is not the leader among the Baltic states in terms of the environmental performance: Estonia holds the 8th position in the ranking, while Latvia and Lithuania - the 22th and 23th, respectively (Environmental Performance Index, 2016). Under the assumption that high forest coverage of a country might significantly add to its reputation of a green country, Latvia and Estonia have a higher percentage of forest cover compared to Lithuania (54\% and $52.7 \%$, respectively against $34.8 \%$ ) (World Bank Group, 2016), thus, there is no less reason to estimate the possibility to position also Estonia and Latvia as green and hence, supporting the green brand of the whole Baltic region.

Separate segments of the green production in Latvia are already being strengthened. Vilcina et al. (2016) argue that Latvian organic dairy farms have a large capacity for development, which can be reinforced by the public procurement scenarios ensured by the policy makers in Latvia. One of such state-supported scenarios is the Sustainable Strategy of Latvia until 2030. Within the framework of the strategy, the guidelines for the national sustainable development being aimed at the transition to the "innovative and eco-efficient economy" in Latvia are defined and currently are being implemented (Saeima of the Republic of Latvia, 2010).

Nevertheless, the opportunity to brand Latvia as a green country is impeded by certain challenges. For instance, disregarding the fact that Latvia has one of the highest percentage of forest area in relation to the land area (54\%), the country cannot be legitimately denoted as "the greenest country of Europe", for Sweden and Finland are the two European countries that overtop Latvia in this respect (World Bank Group, 2016). In addition, as abovementioned, Latvia has the highest percentage of forest area in the Baltics. Yet basing the nation-branding strategy for Latvia on the trivial predominance of the country over the other Baltic countries might be destructive for the sustainability of the Latvian nation-brand due to the weakness of the argument and the possible loss of the regional coherence of the Baltics. Furthermore, being ranked 22 among 180 countries, the sustainability performance of Latvia was still evaluated as lower compared to the countries in the related region (Environmental Performance Index, 2016). As for the Planet \& Climate Global Contribution criterion of Good Country Index, Latvia holds the 43rd place out of 163 . This criterion includes such aspects as ecological footprint, reforestation since 1992, hazardous pesticides exports, $\mathrm{CO}_{2}$ emissions and ozone (Good Country Index, 2016).

Additionally, a challenge to brand Latvia as a green country can be posed by the cultural factor reflected by the public opinion on sustainability measures in Latvia. Researchers from Latvia Briška and Rungule (Briška \& Rungule, 2011) determined that the concern about the environmental problems, as one of the main aspects of sustainable development, in Latvia is faded due to the more publicly pressing problem of the economic issues. In addition, they point out that in order to accept and adapt the environmentally conscious behaviour, the societies should be better-informed about the importance and concepts of the environmental matters (Briška \& Rungule, 2011). Considering that environmentalism is a broadly discussed matter nowadays and in the global sphere, the general understanding of 
the concepts and their importance is being spread, a wider discussion at the national level on the advantages of eco-consciousness for Latvia would be beneficial for the reinforcement of the green brand of the country. In addition, the intensification of the programmes at the institutional level aimed at the improvement of the environmental situation in Latvia should be the subject of closer consideration and practical implementation.

\section{CHALLENGE OF DEFINING THE GEOGRAPHICAL IDENTITY OF LATVIA}

Despite the actuality that the Baltic region is an important geopolitical and transit hub of Europe, to date, there has been little agreement on the geographical identity of the region. In scientific literature (e.g. Cottey, 2008), international organisations such as United Nations (2016) as well as popular informational sources as Wikipedia, the Baltics are classified as Northern Europe. Alternatively, Lithuania, Latvia and Estonia are frequently regarded as Eastern European countries (Anholt, 2005; Leontidou, 2004; Hospers, 2004) or else North-Eastern Europe (Spruds \& Potjomkina, 2016; Hackmann, 2002; Charles, 2009). Apart from symbolic and cultural significance of an unambiguous geographical definition of countries, in the current context, it is conjectured that geographical identity has a substantial impact on the export performance of countries. Direct interrelation between the geographical identity of regions and their economic performance, including, inter alia, exports, can be observed and is expressed, for instance, in the policies for regional development implemented at the supranational level (e.g. the Structural Funds and the Cohesion Fund within the framework of the regional policy of the European Union) as well as historically and culturally formed associations, i.e. prejudices related to the quality, price and status of production, affecting the consumer behaviour.

In 2008, Simon Anholt advised to promote the nation-brand of Latvia via branding the country's capital city Riga as a New North Star. Furthermore, he emphasised that adopting the approach of branding Latvia as a whole "is exactly the wrong thing to do" (Anholt, 2008). Among the arguments for such an assumption was his observation that Latvians have a lack of desire "to share their land with strangers again", that the country is not "highly attractive for many kinds of foreign direct investment" and that Latvia is a comparatively less industrialised country and, therefore, might have "strong ecological arguments for keeping it pristine" (Anholt, 2008). Nevertheless, the national exports as the subject of the research put Anholt's observations and rationale into another perspective. First, the stimulation of exports primarily presupposes the presence of the products of Latvian origin abroad, thus, making the topic of "sharing the land" less relevant for the current context. Second, the "pristine" environment of the country might function as an impulse for the national exports through the promotion of the green brand of Latvia as discussed in the previous section. Focusing the branding strategy solely on the capital city would significantly weaken the potential to represent Latvia as an origin of green production, for the production sites of potential green brands of Latvia are not solely concentrated in its capital. Moreover, the emphasis put on Riga 
might be an impediment to the regional cohesion and the economic development of the regions of the country and, thus, contradict the regional policies at the national (Ministry of Environmental Protection and Regional Development of the Republic of Latvia, 2017) and supranational (European Commission, 2015) levels. Accordingly, even if branding Riga as a New North Star would maintain the association of the county with North Europe, which might be regarded as economically beneficial as discussed further in the text, in the context of the stimulation of the national exports, targeting the geographical positioning of Latvia on city-branding is not prudent. In turn, the shared historical, environmental and societal circumstances of the three Baltic countries might be a more sensible approach to define the strategy of geographical positioning of Latvia.

The shared issue of the disparity of the geographical identity of the Baltics can be accounted for the historical, cultural and political reasons, namely, those that were forced by the repeated change of the political rule. For instance, the Hanseatic times with their cultural, economic and architectural traces, showing their influence to the present day, interconnect the northern countries of Europe. In addition, the current Baltic Sea regional cooperation or European Union Strategy for the Baltic Sea Region - EUSBSR (European Commission, 2009), sometimes referred to as "The New Hansa" (Weever, 1993), supports the association of Latvia as well as Lithuania and Estonia with Northern Europe. Nevertheless, at present, the dominant influence on the geographical identity of the Baltics in many cases is attributed to the Soviet past of the three Baltic countries, which implies the association of the region with Eastern Europe (Szondi, 2007; Dinnie, 2008).

The consequence of such geographical ambiguity is expressed in a combination of tokens peculiar both to Eastern and to Northern Europe. It is evident in the case of timber industry: while the quality of Nordic timber is considered high due to its high density and the Baltic timber falls into this category, the pricing of products and services in the Baltics is considerably lower than in Scandinavia. Thus, some services and products, as timber, of the Baltic origin gain a competitive advantage. Nevertheless, in such industry areas as electronics, the Baltic origin is more likely to be disadvantaged compared to Scandinavia. Therefore, this combination of peculiarities associated with Eastern and Northern Europe is discrete and fluid and thus, might be directed and adapted to the specific branding strategy aims.

The empirical investigation of the expression of the geographical identity of Lithuania, Latvia and Estonia on the websites of their official representatives (Investment and Development Agency of Latvia, Invest Lithuania and Estonian Investment and Trade Agency) shows that the references to the geographical identity of the represented countries occur; however, are neither frequent nor accented. On the Lithuanian representative's website, the references to the geographical identity of the country are remarkably rare and indirectly support the image of Central Europe. On the Latvian website, most frequent references are related to the Northern image of the country; however, North-Eastern Europe as geographical identity as well as its central location is also mentioned. Finally, on the Estonian website, the Northern geographical identity was explicitly defined, yet the Eastern cultural influence is also admitted. The references to the geographical identity of the three countries are reported in Table 1, Table 2 and Table 3. 
Table 1. References to Geographical Identity of Lithuania

\begin{tabular}{|l|l|}
\hline$\sim$ Central Europe & "Perfectly located at the heart of Europe" \\
\hline Eastern/Western Europe & "quick logistical access to both Eastern and Western Europe" \\
\hline Eastern/Western Europe & "[...] a busy trading route between East and West [...] \\
\hline
\end{tabular}

Table 2. References to Geographical Identity of Latvia

\begin{tabular}{|c|c|}
\hline Northern Europe & "Just like a typical Northerner, Riga might seem reserved on the outside, $[\ldots]$ " \\
\hline Northern Europe & $\begin{array}{l}\text { "Situated at the very heart of the economically and culturally vibrant Nordic } \\
\text { Baltic region" }\end{array}$ \\
\hline Northern Europe & "With a Northern European culture, Latvians have a strong work ethic [...]" \\
\hline $\begin{array}{l}\text { Eastern/Western } \\
\text { Europe }\end{array}$ & "Latvia is $[\ldots]$ conveniently located between Eastern and Western Europe." \\
\hline $\begin{array}{l}\text { North-Eastern } \\
\text { Europe }\end{array}$ & $\begin{array}{l}\text { "[...] inhabitants of Latvia live in North-Eastern Europe between Russia and } \\
\text { the Baltic Sea }[\ldots] "\end{array}$ \\
\hline
\end{tabular}

Source: Investment and Development Agency of Latvia (2016)

Table 3. References to Geographical Identity of Estonia

\begin{tabular}{|c|c|}
\hline $\begin{array}{l}\text { Northern and Eastern } \\
\text { Europe }\end{array}$ & "[...] Eastern hospitality and northern conservativeness $[\ldots] "$ \\
\hline Northern Europe & $"[\ldots]$ an introverted Nordic people $[\ldots] "$ \\
\hline Eastern/Western Europe & "“...] a busy trading route between East and West $[\ldots] "$ \\
\hline Northern Europe & "Nordic influence. We live in a Nordic country." \\
\hline Eastern Europe & $\begin{array}{l}\text { "The eastern influence. We ourselves come from the East, and many } \\
\text { people have come here from the East. It would be naïve to think that } \\
\text { we have no relation with the [land of the] rising sun. We have inherited } \\
\text { our generally quite hospitable nature from the East. Also, our present } \\
\text { educational background has discernible Eastern influences.' }\end{array}$ \\
\hline Northern Europe & $\begin{array}{l}\text { "We belong to the North and form a part of one of the most valuable } \\
\text { regions of Europe, the core of which is Scandinavia. }\end{array}$ \\
\hline $\begin{array}{l}\text { Central and Eastern } \\
\text { Europe }\end{array}$ & $\begin{array}{l}\text { "[...] Estonia has been one of the most outstanding countries for its } \\
\text { average level of education in Central and Eastern Europe." }\end{array}$ \\
\hline
\end{tabular}

The possible options for geographical definition of Latvia are threefold. The first option would be the advancement of the "Northern" image of the country. Despite the positive influence on the perception of the quality of life as well as product and service appraisement, the favourable outcome of the "Northern" image might be impeded by the cultural transition of the population, which requires a longer period of time. An alternative option would be the development of the advantages peculiar to the "Eastern" image. However, the strategy most likely will 
be confronted by a part of the local population due to the observed contemporary strive for estrangement from the image of Eastern Europeans and inclination towards the mentality of Northern Europeans. A further alternative way to position the brand of the country is the geographical identity of Latvia as North-Eastern Europe, which would provide the nation branding strategies with the needed flexibility and adaptability. However, also this option has disadvantages, as the inconsistency with the definition of the Baltic region by the European Commission, i.e. the Baltics as a separate region as well as a part of Central-Eastern Europe (European Commission, 2014). Apart from the three aforementioned options for the geographical aspect of nation-branding, which have both advantages and disadvantages and need an in-depth critical analysis, further strategies for geographical identification of Latvia include a targeted positioning of the Baltic region as Central-Eastern Europe.

\section{CHALLENGE OF THE FINANCIAL IMAGE OF LATVIA}

The issue of the controversial financial image of Latvia, firstly, is closely related to the indefinite geographical identity of the Baltic region. As it was mentioned in the previous section, Latvia is frequently referred to as an Eastern European country. Szondi (2007) argues that the image of Eastern Europe has a certain set of associations, and poverty is one of them (Szondi, 2007). Moreover, he states that, in the framework of destination branding, Eastern European countries position themselves as "inexpensive, affordable, modern, sunny and welcoming" (Szondi, 2007). Furthermore, Central and Eastern European countries, an alternative region to what Latvia is frequently ascribed to, "do not create strong and positive associations for Western Europeans. Accordingly, the associations with Eastern Europe and Central and Eastern Europe are commonly related to low expenses, and Latvia falls into this category. In addition, each country of the region does not have definite hallmarks, which would distinguish them one from another on the international scale (Szondi, 2007). Due to the absence of reference points other than monetary, the image of the countries of the region is based on widely known and generalised facts and the reputation of the region of being cheap is being reinforced.

The problem with being branded as a cheap country is evident on international outsourcing and offshoring activities. As generally known, one of the main incentives to outsource is the reduction of costs (St. Amant, 2010). For instance, Latvia was seen by the Norwegian companies "as a country with cheap labour and raw materials and logistics" (Cimdina, 2008). Thus, a large number of foreign enterprises locate their production sites in the Baltic countries due to the low labour costs compared with Western-European and Nordic countries. In addition, by evaluating the factors which influence the competitiveness of offshoring destinations such as "infrastructure, IT personnel availability, capital and entrepreneurship", Lithuania, Latvia and Estonia are seen as a region offering promising markets for cross-border cooperation in the area of IT due to "some of the highest numbers of scientists and engineers in research and development per million people" (Cimdina, 2008). Also the Investment and Development Agency of 
Latvia mentions "skilled and motivated workforce" and "cost-effectiveness" as the beneficial factors for foreign investors as well as highlights that Latvia holds the second position (after Romania) in the rating of "the advantageous wage adjusted labour productivity" (LIAA, 2016).

While this competitive advantage resulting from the highly skilled and lowpaid labour force is beneficial for the foreign investment in Latvia, these factors also prescribe certain economic bias, which, in turn, impede the redefinition of the financial brand of the country. In other words, since Latvia is internationally known for the low-paid but qualified labour force, which has become a fixed set of expectations about the country on the global market, these expectations function as a force to hinder the increase of the cost of labour through the imposed expectations of the potential international cooperation partners and foreign investment.

Nevertheless, researchers (e.g. Meel \& Saat, 2000) see high labour costs as "one of the most serious problems in North and West Europe" and assume that the influx of the low-paid but skilled labour from the Baltics into the free market network of the European Union will stabilise the European economy (Meel \& Saat, 2000). Nation-branding, in turn, is considered to be able to neutralise the negative forces that impede the economic development as well as the image of a country (Dinnie, 2008). Alongside with the simultaneously changing economic environment in Europe, a nation-branding strategy aimed at positioning Latvia in a certain niche segment, as, for instance, eco-consciousness as discussed in the previous section, could redirect the image of Latvia and positively influence its exports. Alternatively, the redirection of the statement "cheap working force in Latvia" to "production for reasonable prices in Latvia", which linguistically offers a scope for interpretation and does not rigidly frame the pricing expectations, might be an option for further consideration.

\section{RESULTS}

The research results into a threefold groundwork for identification and examination of three challenges of nation-branding of Latvia affecting the present and prospective export performance of the country. The findings assert that branding Latvia as a green country has a considerable potential, the fulfilment of which is a matter of time, for much advancement in the direction of sustainable development is being made in the country. The research adds that the cultural factor plays a vital role in the dynamics and the direction of the formulation of the green brand of Latvia and the society should be better informed about the environmental matters. Next, the research maintains that there is a remarkable degree of uncertainty around the issue of geographical identity of Latvia (mainly Eastern or Northern Europe), which has its negative consequences on the brands of the three countries and their export potential. Further, the research illustrates and interprets the brand of Latvia as a cheap country and its contradiction to the desired and desirable image. Moreover, the research discusses the perceived economic state of the country as well as the impediments and possible ways for the estrangement from the reputation of a country related to the region of low-paid labour. 


\section{CONCLUSION}

The research concludes that the provisionally defined challenges expressed in the inconsistency of the tokens of Latvia's image affecting its brand are proven to be actual and have an effect on the export performance of Latvia. Nevertheless, within the present research it is assumed and argued that the current challenges of nation-branding of Latvia might be used as an opportunity with big potential for the development of a strong brand of the country rather than an obstacle for it. For this, the possible factors that would further develop the green brand of Latvia should be defined, estimated and implemented. The geographical identity of the country should be directed and precisely and consistently communicated internally and externally. The influence of the nation-brand based on the combination of costefficiency of production and high proficiency of the labour force on the national economy and the actual potential of the current competitive advantage of Latvia should be scrutinised and evaluated and, possibly, strategically formulated. The research on the experience of nation-branding performed by other countries should be taken into close consideration to facilitate the development of the nationbranding strategy for Latvia. Then, actions taken to increase the literacy of the population of Latvia in respect to the importance and the essence of the nationbranding strategy would be beneficial for the further strengthening of the nationbrand and, thus, potentially, have a positive influence on national exports. Finally, the discussion on the three defined challenges of nation-branding of Latvia adverted to the possibility to reinforce the brand of Latvia as a green country, which would advance a clear formulation of the nation-branding strategy of the country and concurrently distinguish and strengthen certain segments of the Latvian economy on global scale.

\section{ACKNOWLEDGMENT}

The research was supported by the National Research Program 5.2. EKOSOC-LV.

\section{REFERENCES}

Anholt, S. (2005). Brand New Justice: How branding places and products can help the developing world. Oxford: Elsevier Butterworth-Heinemann.

Anholt, S. (2008). A Competitive Identity for Latvia: Interim Strategy Paper. Retrieved from http://www.li.lv/images_new/files/pdf/strategy_latvia.pdf

Baltiņa, L. (2014). Uz vietu balstītas pieejas izmantošana reǵionālās attīstības plānošanas pilnveidošanai Latvijā. (Doctoral dissertation, University of Latvia). (in Latvian)

Brencis, A. (2015). Mārketinga vadības metožu izmantošana Latvijas pašvaldībās. (Doctoral dissertation, University of Latvia). (in Latvian)

Briška, I., \& Rungule, R. (2011). Sustainable Development: Changes in the Evaluation of Environmental Risks in Latvia. Management Theory and Studies for Rural Business and Infrastructure Development, 25, 36-43.

Charles, A. (2009). Media in the Enlarged Europe: Politics, Policy and Industry. Bristol/Chicago: Intellect.

Che-Ha, N., Nguyen, B., Yahya, W. K., Melewar, T., \& Chen, Y. P. (2016). Country branding emerging from citizens' emotions and the perceptions of competitive advantage. Journal of Vacation Marketing, 22(1), 13-28. https://doi.org/10.1177/1356766715586454 
Cimdina, A. (2008). The Otherness of Eastern Europe? The Socially Constructed Marketplace as an International Business Arena. In I. Schröder \& A. Vonderau (Eds.), Changing Economies and Changing Identities in Postsocialist Eastern Europe (pp. 129-154). Münster: LIT Verlag.

Cottey, A. (2008). Europe's New Subregionalism. Journal of Strategic Studies, 23(2), 23-47. https://doi.org/10.1080/01402390008437789

Cull, N. J. (2013). EHU Public Conversation: Nation Branding. Retrieved from https://www.youtube.com/watch?v=zrIyiYHmqhI

Dinnie, K. (2008). Nation Branding: Concepts, Issues, Practice. London/New York: Routledge.

Endziņa, I., \& Luneva, L. (2004). Development of a Nation Branding Strategy: The Case of Latvia. Place Branding, 1(1), 95-105. https://doi.org/10.1057/palgrave.pb.5990009

Environmental Performance Index. (2016). Full Report 2016. Retrieved from http://epi.yale.edu/

Estonian Investment and Trade Agency. (2016). Why Estonia? Retrieved from http://www.investinestonia.com/en/about-estonia

European Commission. (2009). EU Strategy for the Baltic Sea Region, EUSBSR.

European Commission. (2014). Investment for Jobs and Growth. Promoting Development and Good Governance in EU Regions and Cities. Sixth Report on Economic, Social and Territorial cohesion. Luxembourg: Publications Office on the European Union. Retrieved from http://ec.europa.eu/regional_policy/sources/docoffic/official/reports/cohesion6/6cr_en.pdf

European Commission. (2015). Policy. Territorial Cohesion. Retrieved from http://ec.europa.eu/regional_policy/en/policy/what/territorial-cohesion/

Frasher, S., Hall, M., Hildreth, J., \& Sorgi, M. (2003). A Brand for the Nation of Latvia. Oxford Said Business School, $60 \mathrm{p}$.

Good Country Index. (2016). Overall Rankings. Retrieved from https://goodcountry.org/index/overall-rankings

Hackmann, J. (2002). From "Object" to "Subject": The Contribution of Small Nations to RegionBuilding in North Eastern Europe. Journal of Baltic Studies, 33(4), 412-430. https://doi.org/10.1080/01629770200000201

Hospers, G. J. (2004). Regional Economic Change in Europe: a Neo-Schumpeterian Vision. New Brunswick, London: Transaction Publishers.

Iannuzzi, A. (2012). The Making and Marketing of Sustainable Brands. Boca Raton/London/New York: CRC Press.

Invest Lithuania. (2016). Let's Talk Lithuania. Retrieved from http://www.investlithuania.com/letstalk-lithuania/lifestyle/

Investment and Development Agency of Latvia - LIAA. (2016). About. Retrieved from http://www.liaa.gov.lv/en

Latvian Institute. (2016). About Latvian Institute. Retrieved from http://www.li.lv/en/latvian-institute.

Leontidou, L. (2004). The Boundaries of Europe: Deconstructing Three Regional Narratives. Identities, 11(4), 593-617. https://doi.org/10.1080/10702890490883876

Meel, M., \& Saat., M. (2010). International Enterprises and Trade Unions. In J. Sójka \& J. Wempe (Eds.), Business Challenging Business Ethics: New Instruments for Coping with Diversity in International Business: The 12th Annual EBEN Conference (pp. 117-123). Dordrecht: Springer Science \& Business Media. https://doi.org/10.1007/978-94-011-4311-0

Ministry of Economics of Republic of Latvia. (2015). Eksports. Retrieved from https://www.em.gov.lv/lv/nozares_politika/nacionala_industriala_politika/eksports/

Ministry of Environmental Protection and Regional Development of the Republic of Latvia. (2017). Ministry. Retrieved from http://www.varam.gov.lv/eng/par_ministriju/

Mugobo, V. V. (2014). Public diplomacy in the global age: Lessons from literature and practice. $\begin{array}{lllll}\text { Mediterranean Journal of } & \text { Social }\end{array}$ https://doi.org/10.5901/mjss.2014.v5n27p42

Saeima of the Republic of Latvia. (2010). Sustainable Strategy of Latvia until 2030. Retrieved from http://www.pkc.gov.lv/images/LV2030/LIAS_2030_en.pdf

Spruds, A., \& Potjomkina D. (2016). Latvia and the United States: Revisiting a Strategic Partnership in a Transforming Environment. Riga: Latvian Institute of International Affairs.

St. Amant, K. (2010). IT Outsourcing: Concepts, Methodologies, Tools, and Applications. Hershey, London: IGI Global. 
Szondi, G. (2007). The Role and Challenges of Country Branding in Transition Countries: the Central and Eastern European Experience. Place Branding and Public Diplomacy, 3(1), 8-20. https://doi.org/10.1057/palgrave.pb.6000044

United Nations. (2016). United Nations Statistics Division. Composition of macro geographical (continental) regions, geographical sub-regions, and selected economic and other groupings. Retrieved from http://unstats.un.org/unsd/methods/m49/m49regin.htm

Van der Steina, A. (2012). Latvijas kā tūrisma vietas mārketinga darbības efektivitāte. (Doctoral dissertation, University of Latvia). (in Latvian)

Vilcina, A., Grinberga-Zalite, Mazure, G., \& Dumpe, E. (2016). Opportunities for Development of Organic Milk Production and Processing in Latvia. Engineering for Rural Development, 15, $102-108$.

Vira, R., Lingerberzins E., Strele I. \& Fogelmanis, K. (2012). National Identity in Latvia for Effective Place Marketing. West East Journal of Social Sciences, 1(1), 1-10.

Vozņuka, J. (2010). Teritoriāla mārketinga koncepcijas izmantošana Latgales reǵiona attīstībā. (Doctoral dissertation, University of Latvia). (in Latvian)

Weever, O. (1993). Culture and Identity of the Baltic Sea Region. In P. Joenniemi (Ed.), Cooperation in the Baltic Sea Region (pp. 23-33). Washington, London: Taylor \& Francis.

World Bank Group (2016). Forest area. Retrieved from http://data.worldbank.org/indicator/AG.LND.FRST.ZS

\section{AUTHORS' SHORT BIOGRAPHIES}
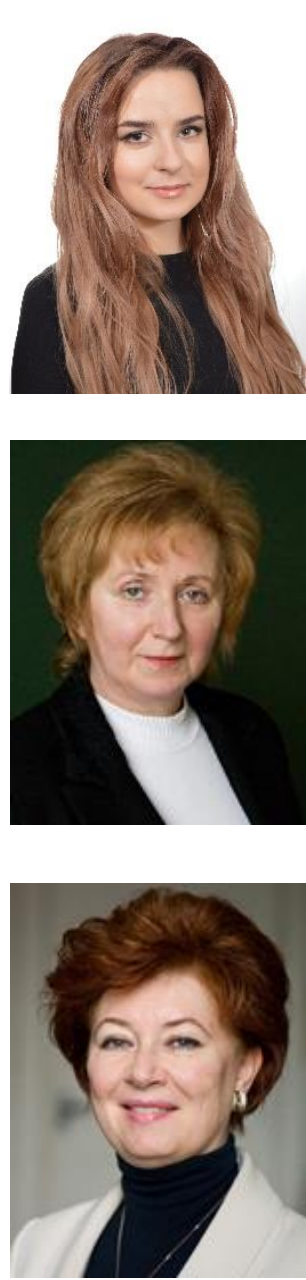

Angelina Bekasova received the Master's Degree in Humanities from the University of Latvia after defending the Master's thesis on the topic "Intercultural and Transcultural Communication in the Context of European Export Management. Case Studies: Germany, Latvia, Russia and Italy". Her main fields of professional and academic activity are export management, intercultural and transcultural communication, linguistics and non-formal education. She is a scholarship holder of Deutsch-Baltisches Jugendwerk (DBJW).

Phone: +37129366800

E-Mail: angelina.bekasova@gmail.com

Biruta Sloka, Dr. oec., is a Professor with the University of Latvia. She has participated in several research projects. She is Head of the Euro Faculty Riga Centre. She is a Member of the Latvian Association of Econometrists, Member of Association of Professors of Higher Education of Latvia and the President of the Latvian Association of Statisticians.

Address: Faculty of Economics and Management, University of Latvia, 5 Aspazijas Blvd., Riga LV-1050, Latvia

Phone: +371 29244966

E-mail: biruta.sloka@lu.lv

Tatjana Muravska, Dr. oec., is a Professor with the University of Latvia and Jean Monet Chair, she has participated in many research projects, has organised many international scientific conferences and has published several monographs and research papers.

Address: Faculty of Economics and Management, University of Latvia, 5 Aspazijas Blvd., Riga LV-1050, Latvia

Phone: +371 67034795

E-mail: tatjana.muravska@lu.lv 